\author{
Ágnes Tóth \\ Centre for Social Sciences, Budapest \\ toth.agnes@tk.mta.hu
}

\title{
Research Questions and Methodological Approaches in the Literature on the History of the German Minority in Hungary between 1945 and 1990
}

In my study, I summarise the content issues, methodological approaches and the most important results of the historical literature dealing with the history of the German minority in Hungary during the decades after the Second World War till the change of regime. In connection with both the content and methodological issues, I will touch on - in my opinion - the missing aspects, the possibility of more complex research approaches. Although my study focuses on the literature on the history of the Germans in Hungary between 1945 and 1990, due to the connections, I will also briefly touch on the works between the two world wars. I could not ignore the historiographical and bibliographic research related to the history of the German nationality and the works that condense their general political, economic and social situation across epochs. How and with what weight the period under discussion appears in these comprehensive works reveals a lot about the yet unidentified and unaccounted research elements.

From the early 1980s, Hungarian and international research, especially German research, influenced each other and so I also touch on these interactions in my review. However, in the case of the works referred to in connection with the individual content priorities, I do not try to be complete, but to show their thematic and methodological diversity.

I did not include in the scope of historiographical analysis the so-called works of compatriotic (landsmannschaftlich) historiography, or the Heimatbuchs. I decided this because these works, in large measure, raise settlement and family history issues, and 
although they often provide important, interesting documents and facts not available elsewhere for micro-historiography, they are non-professional, uneven in their level and extremely diverse in their genre. On the other hand, most of these works interpret the role contemporaries (Erlebnisgeneration) played in the events, justifying their earlier actions. The processes and events are viewed subjectively through the effects of their own local world. The aim of these works was not to explore the history and social relations of the given settlement, but rather to preserve the retrospective frozen home image of the expellees. ${ }^{1}$

I did not consider it expedient to include the general works on the history of Hungary in the scope of the historiographical analysis. Although, most of these works deal with the state of the German minority in a certain way and extent, their state is concerned primarily in the aspects of the majority society and the nationwide processes, primarily. Thus, few or no attention is paid to the analysis of their interference or interrelation that is key issue of their coexistence.

Thus, below, I summarise the focus of the content and the methodological approaches of the literature on the recent history of the German minority in Hungary, dividing it into three groups: historiographical-bibliographic research; comprehensive, cross-periodical works; the general political, economic and social situation of the German minority.

\section{Historiographical and Bibliographic Works}

The obvious result of the historiographical and bibliographic research is that, on the one hand, the results can be seen together, showing the state of the given research area, what kind of questions were asked, what methodology was used, and what answers were given. On the other hand, the white spots are highlighted, thereby inspiring further explorations. Research on the history of the minorities in Hungary was stimulated by the activities of the Bibliography Working Group of the National Gorky Library's Centre for Nationality, Public Culture Research and Documentation, which began in the late 1970s and became the coordination centre for basic and specialised ethnic libraries. The multi-volume complex publication entitled "Nationalities in Hungary", published by them, containing thousands of pages and tens of thousands of data, effectively supported the research. The volumes edited by István Käfer have been published continuously since 1983, and include bibliographic data on the lives of Germans, Romanians, Slovaks

1 See more on this W. Kessler, Ost- und südostdeutsche Heimatbücher und Ortsmonographien nach 1945. Eine, Bibliographie zur historischen Landeskunde der Vertreibungsgebiete. de Gruyter, München 1979; M. Beer (ed.), Das Heimatbuch. Geschichte, Methodik, Wirkung, V§R Unipress Verlag, Tübingen 2010; K. Takács Oroszné, "Zwischen Mythos und Realität. Historische Kulminationspunkte in Heimatbüchern der ungarndeutschen Vertriebenen", in: M. Fata (ed.), Migration im Gedächtnis: Auswanderung und Ansiedlung im 18. Jahrhundert in der Identitätsbildung der Donauschwaben, Franz Steiner Verlag, Stuttgart 2013, pp. 135-154, and eadem, "Heimat im Buch: Ungarndeutsche Heimatbücher als Antwort auf die Fragen der Migration", in: T. Radek, A. Szilágyi-Kósa (ed.), Wandel durch Migration, Veszprém Magyar Nemzeti Levéltár Veszprém Megyei Levéltára, Veszprém 2016, pp. 205-219. 
and South Slavs (Serbs, Croats, Slovenes) in the period 1945-1975. They contain articles and studies related to ethnicity in daily and weekly newspapers and magazines, published independent volumes, and articles on the subject published abroad. ${ }^{2}$

The joint project of the László Teleki Foundation and the Südost-Institut in Munich is significantly larger in volume and significance, in which not only a bibliography of publications related to the history of the 35 minority groups of the successor states of the Habsburg Monarchy between 1918 and 1990 was processed, but in the first chapter of the volume, more general works related to the topic are published, and several maps and statistical compilations help to provide further information. ${ }^{3}$ It would have been important - which was the original idea of the project leaders, Péter Dippold and Gerhard Seewann ${ }^{4}$ - to constantly update the database of bibliographic manual and supplement it with new content, available online. However, this was circumvented by the reorganisation of the two institutes, the removal of the research profile of the László Teleki Institute, and the lack of financial resources.

\section{Comprehensive, Cross-periodical Works}

Among the comprehensive, cross-periodical, regional-level studies of ethnic problems, the international research entitled Germans and Hungarians as National Minorities in the Danube Basin 1918-1980 and the Minority Issue in Southern Europe stand out, the results of which have been published in volumes of studies. These are a good indication of the change that took place in the field of minority research in the decade between the two projects. The starting point of the study focusing on the situation of the German and Hungarian minorities was that clarification of the concepts should be linked to methodological renewal, and instead of a descriptive interpretation of the problems, different possibilities of interpretation should be sought and the behaviour and social situation of ethnic groups, embedded in the economic and social processes of the given area, should be examined. It was also strongly emphasised that the application of a comparative methodology is unavoidable in order to establish ethnic fault lines within a given society. Accordingly, the published studies placed the development of the minority issue in the context of the modernisation of the Central and Eastern European states. From the point of view of nationalities, the features of language policy and the role of language in ethnic group formation were examined in both countries. In his studies, Gerhard Seewann, on the one hand presents the situation of the Germans between 1918 and 1988 in the light of Hungarian nationality policy,

2 I. Fehér, Az utolsó percben. Magyarország nemzetiségei 1945-1990, Kossuth Kiadó, Budapest 1993, p. 17. A bibliography on the history of German Nationality was first published in 1983. See: I. Käfer (ed.), Németek Magyarországon 1945-1975. Bibliográfia, Vol. 1-2, Állami Gorkij Könyvtár, Budapest 1983.

3 G. Seewann, P. Dippold (eds), Bibliographisches Handbuch der ethnischen Gruppen, Vol. 1-2, R. Oldenbourg Verlag, München 1997.

4 Gerhard Seewann pályájára vonatkozóan lásd “A különböző kultúrák együtt-létezése, egymásra hatása óriási élmény volt számomra." Beszélgetés Gerhard Seewannal. Az interjút készítette Tóth Ágnes, Aetas 2010, No. 1, pp. 182-192. 
and on the other hand attempts to identify the typological features of the German and Hungarian minorities in the Carpathian Basin. ${ }^{5}$ The volume related to the minority issue in Southern Europe, published a decade later, focuses on the concepts used - ethnicity, people, nation, identity - and the definability of different group identities, as well as the impact of structural changes on minorities. ${ }^{6}$

In the previous decade, a major venture commenced with the aim of publishing the history of the German minority communities from the beginning till the end of World War II in several volumes. Günter Schödl, the editor and largely the author of the volume on the Danube Basin and Hungary, outlined the need of claiming the process of the history of Germans living in the region based on a mutual concept with special regard to their differences and reasons in the introduction of the above-mentioned volume. ${ }^{7}$

The thematic and methodological changes can also be well observed in Gerhard Seewann's volume of studies, in which the author collected his works from the mid-1970 s related to the history of the Germans in Hungary. The focus of his research is, on the one hand, the main features of the $20^{\text {th }}$ century nationality policy, the role of the minority issue in domestic and foreign policy, and, on the other hand, the factors influencing the identity constructions of Hungarian and, especially, German minority groups and certain specific minority historical events. ${ }^{8}$

So far, only Gerhard Seewann has undertaken to write a monograph of the history of the Germans in Hungary from the Middle Ages to the middle of the $21^{\text {th }}$ century. Undoubtedly, the monumental work published in German and Hungarian in recent years is the largest undertaking till now. ${ }^{9}$ The great advantage of works written with a monographic demand is that the subproblems are shown in the whole process, in their cause and effect relationship. At the same time, the authors of the syntheses can only build on the existing results, i.e. in the framework of the given work there is usually no way to eliminate the gaps and inequalities of previous research. In his comprehensive work, Seewann attempts to examine the narration of the group history of the Germans in Hungary from the perspective of their interethnic relations with Hungarians and other minorities. He looks at the community as a subject, a shaper of his destiny, a performer, and not as an object of some kind, a victim of events. Admittedly, it was a great challenge for him to break with the tradition of nation-centred Hungarian historiography, and place the history of the Germans living in Hungary at any given time in a broader context. He discusses the history of the country in the context of

G. Seewann, "Das Ungarndeutschtum 1918-1988. and Ungarische und deutsche Minderheiten im", in: E. Hösch and G. Seewann (eds), Aspekte ethnischer Identität, Oldenbourg Verlag, München 1991, pp. 299-323, 395-409.

6 Idem(ed.), Minderheitenfragen in Südosteuropa, Südost-Institut-Oldenbourg Verlag, München 1992.

7 Deutsche Geschichte im Osten Europas. Land an der Donau. Hrsg. Günter Schödl. Siedler Verlag, Berlin 1995.

$8 \quad$ Idem, Ungarndeutsche und Ethnopolitik, Osiris-MTA Kisebbségkutató Mühely-Magyarországi Németek Országos Önkormányzata, Budapest 2000.

9 Idem, Geschichte der Deutschen in Ungarn, Vol. 1: Vom Frühmittelalter bis 1860; Vol. 2: 1860-2006, Herder Institut, Marburg 2012; idem, A magyarországi németek története, Vol. 1: A kora középkortól 1860-ig; Vol. 2: 1860-2006, Argumentum Kiadó, Budapest 2015. 
European processes, for which he used the results of transnational historiography. Relying on a huge source and literature base, the author draws up a plastic and differentiated picture of the history of the Germans in Hungary, placing it in the processes occurring in the region, and examining their situation in constant comparison with Hungarians and other minorities.

As can be observed in other works prepared with the need for synthesis, due to the unevenness of the available research results, the presentation of an era necessarily has different depths. The author himself draws attention to this when he points out that many issues in the history of the Germans in Hungary in the $18^{\text {th }}$ and $20^{\text {th }}$ centuries are still unexplored. The sketchiest part of the work is the chapter dealing with the period 1949-1989-2006, which also points to the research gaps. From the point of view of the history of the German minority, the author divides the socialist era into three periods: (1) escape, expulsion, political discrimination, social disdain, (2) profound social changes, (3) the long-lasting liberalisation of political and cultural life that began in 1983. We can basically agree with this, but the systematic examination of the period will make it possible to map further subperiods. As we can see, the points of intersection over time are fundamentally determined by which the research aspects are of our study. That is, we can set different time limits if we look at what is happening from the point of view of nationality policy decisions, their impact on the minority, or the reactions of the community.

Examining the post-1948 socialist era, the author's starting point is natural, since in socialism the political authorities treated the society as an object, with the formation of an independent group out of the question. Thus, ethnic associations dedicated to the representation of minorities did not, or only to a very limited extent, represent these communities. Although the political authorities eliminated the collective legal drawbacks of the Germans in Hungary in 1953, in practice they maintained the stigmatisation until the end of the 1960s. Compared to other national minorities in Hungary, the political authorities allowed the Germans to form the German Association or the possibility of mother tongue education almost a decade later. I agree with Seewan that the minorities were the objects and not the subjects of socialist nationality policy until the early 1970s, and the negative impact of this factor was compounded with the also negative consequences of political and economic structural change on nationalities. At the same time, I would not underestimate the role of community-building organisations and initiatives, such as ethnic associations or local cultural groups that move within a narrow framework, planned and controlled, in long-term processes.

\section{Works on the Social State of the German Minorities}

The research related to the general political and economic and social situation of the German minority in Hungary in the $20^{\text {th }}$ century unfolded in the first half of the 1970 s, which was characterised by temporal linearity. ${ }^{10}$

10 I rely on my previous writing below: Á. Tóth, "Mi híja még? A magyarországi németek kitelepítése a hazai történetírásban: tematikai fehérfoltok, módszertani hiányok", in: A. Grósz (ed.), Jogfosztások Budaörsön 1944-1948, Bleyer Jakab Helytörténeti Gyüjtemény, Budaörs 2010, pp. 17-30. 
The related specialist studies and monographic elaborations discussed the connections between Hungarian foreign policy aspirations and nationality policy, the relationship between Germany and the German minority in Hungary, and the role of the issue of nationality in territorial revisions. Besides, the volumes of studies presenting the SS-recruitments and the history of the Volksbund, which assessed the aspirations of the German minority in a more nuanced way than before, were of great importance. In this period, the processing and interpretation of the legal framework and regulations concerning the situation of the Germans in Hungary after the Second World War was also thematised for the first time. Raising this aspect has somewhat removed the judgement of the Germans from the previously prevailing ideological approach, now giving way to scientific evaluation. ${ }^{11}$ The interpretations of basically descriptive works are, of course, not free from the ideological determinants of the age, from the one-sided interpretations. At the same time, a huge amount of factual material has been lined up compared to previously, which in itself has paved the way for diverse or different interpretations. The one-sidedness of this research is indicated by the fact that it has a purely political-historical approach, no social or economic-historical aspects, and we can hardly meet the functioning of minority cultural institutions, schools, the legal regulation of ethnic education between the two world wars and its content elements.

Research on the general political and social situation of Germans in Hungary in connection with aspirations for political power in the period between the two world wars continued intensively in the 1990s and after the change of regime. Older researchers who have been dealing with the topic for decades - above all, Loránt Tilkovszky - have sought to synthesise their own work so far, while young historians - Norbert Spannenberger, Zsolt Vitári - have sought to revise previous research and eliminate the thematic white spots. ${ }^{12}$

${ }_{11}$ Without attempting to be comprehensive, I would like to mention only a few professional works from this period, which also bring something new into this topic, its approach and evaluation: J. Komanovics, "A hazai németség volksbundista - illetve hüségmozgalmi - szervezkedése, különös tekintettel Baranya megyére”, in: L. Mándoki (ed.), Janus Pannonius Múzeum Évkönyve 1969/1970, Janus Pannonius Múzeum, Pécs 1970, pp. 183-193; idem, "Hüséggel a hazához a német lakosság náciellenes szervezkedése a II. világháború éveiben". Baranyai Müvelödés 1973, No. 4, pp. 115-119; L. Tilkovszky, SS-toborzás Magyarországon, Kossuth Kiadó, Budapest 1974; J. Komanovics, "A hazai németek helyzetére vonatkozó rendelkezések a II. világháborút követő években 1945-1950", Baranyai Müvelödés 1976, No. 1, pp. 127-133; L. Tilkovszky, "Németország és a magyarországi német kisebbség 1921-1924”, Századok 1978, No. 1, pp. 3-48; idem, Ez volt a Volksbund. A német népcsoport politika és Magyarország 1938-1945, Kossuth Kiadó, Budapest 1978; idem, “Törekvések a magyarországi német mozgalom radikalizálására 1932-1933”, Századok 1979, No. 3, pp. 421-477; B. Bellér, A magyarországi németek rövid története, Magvető Kiadó, Budapest 1981; L. Tilkovszky, “A magyarországi német nemzetiségi kérdés a budapesti osztrák követség jelentéseinek tükrében 1918-1938”, in: I.T. Berend (ed.), A Magyar Tudományos Akadémia Filozófiai és Történettudományok Osztályának Közleményei, Akadémiai Kiadó, Budapest 1981, pp. 111-124.

12 Of these works, I would like to highlight the following: L. Tilkovszky, Hét évtized a magyarországi németek történetéböl 1919-1989, Kossuth Kiadó, Budapest 1989; idem, Nemzetiség és magyarság. Nemzetiségpolitika Magyarországon Trianontól napjainkig, Ikva Kiadó, Budapest 1994; idem, Német nemzetiség magyar hazafiság. Tanulmányok a magyarországi németség történeté- 
During these years, several members of the community living in Germany became involved in clarifying the controversial issues and differing viewpoints, and their works were published in Hungarian as well. ${ }^{13}$

The research into the history of forced migration related to the German and Hungarian minorities after the Second World War was taboo until the mid-1980s. In the first works, the expulsion of the Germans appeared as a segment of the Hungarian transformation after 1945, as a side aspect of it, and with mainly its foreign policy aspects coming to the fore. ${ }^{14}$ The first monographic elaboration was published in 1988 by István Fehér. ${ }^{15}$ The positive result of the work, which relies on knowledge of the research published so far and on the various archival sources, is that it presented the events in a much larger source base than before, in more detail, with many local examples. At the same time, he examined the expulsions practically on their own, snatched from the international and domestic processes, and did not pay enough attention to the interactions of various phenomena. Thus, in many cases, his explanations and interpretations are motivated from a political point of view, and they are one-sided and summative. In the second half of the ' $80 \mathrm{~s}$, the research focused on locality and regionalism. The exploration of the county archives made it possible to present the operating mechanisms, below national level, the leaders and members of the German national movement between the two world wars. These researches clearly highlighted the gap between the legal regulation and implementation of expulsions, the interactions between the expellers, local officials and members of society, and the expellees. It was also at that time that the first sources reported about Germans being deported for forced labour, the so-called Malenkij robot. Turning to the locality necessarily strengthened the bottom-up and personal perspective. ${ }^{16}$

ből, Janus Pannonius Tudományegyetem, Pécs 1997; idem, Nemzetiségi politika Magyarországon a 20. században, Csokonai Kiadó, Debrecen 1998; B. Bellér, A Volksbildungsvereintól a Volksbundig, Új mandátum Kiadó, Budapest 2002; N. Spannenberger, A magyarországi Volksbund Berlin és Budapest között 1938-1944, Lucidus Kiadó, Budapest 2005; Z. Vitári, A Hitlerjugend és Délkelet-Európa, Gondolat Kiadó, Budapest 2012; idem (ed.), Volksbund és ifjúság. Dokumentumok a magyarországi német ifjúság történetéböl 1925-1944, Kronosz Kiadó, Pécs 2015; G. Seewann, N. Spannenberger (eds), Akten des Volksgerichtsprozess Franz A. Basch Volksgruppenführer der deutschen in Ungarn Budapest 1945-1946, Oldenbourg Verlag, München 1999.

13 Dr. Johann Weidlein, A magyarországi németség küzdelme fennmaradásáért. Dokumentáció 1930-1950. Suevia Pannonica, 1996, Paul Flach: Waschkut. München 1983.

14 S. Balogh, A népi demokratikus Magyarország külpolitikája 1945-1947, Kossuth Kiadó, Budapest 1982. E kötetnek a bövitett átdolgozott kiadása a Magyarország külpolitikája 1945-1950, Budapest 1988; S. Balogh, L. Izsák, Pártok és pártprogramok Magyarországon 1944-1948, Tankönyvkiadó (Textbook Publishing House), Budapest 1979; M. Korom, Magyarország ideiglenes nemzeti kormánya és a fegyverszünet 1944-1945, Akadémiai Kiadó, Budapest 1981.

15 I. Fehér, A magyarországi németek kitelepitése 1945-1950, Akadémiai Kiadó, Budapest 1988.

16 Some of the studies and volumes that provided new content during this period through the mentioned topics, approach or source base: L. Szita, "A magyarországi németség iskolaügyének alakulása a Délkelet-Dunántúlon 1938-1944”, in: L. Szita (ed.), Baranyai Helytörténetírás, Baranya Megyei Levéltár, Pécs 1981, pp. 441-55; T. Bognár, "Kitelepítés Szulokból, a második világháború után”, in: J. Kanyar (ed.), Somogy Megye Múltjából 16, Somogy Megyei Levéltár, 
Overall, it can be said that the historical research on the expulsion of Germans from Hungary up to 1990, the change of regime, was characterised by a positivist, descriptive, event-centric approach. The questions of this research were basically organised by the Potsdam legend and the relation to it. Namely, these works interpreted the expulsion of the Germans from Hungary only as foreign policy coercion, a prescription of great powers, and did not deal with the efforts of the Hungarian political parties and governments to do so. The independent scope for action of the Hungarian governments, their own competency and responsibility were not analyzed. It can be explained by the fact that besides the correspondence to the political power, a large number of documents - including the documents of the Ministry of Interior and Foreign Affairs, the Prime Minister's Office and state security organizations - were hardly available for researchers till the second half of the 1980s. ${ }^{17}$ It was only after the change of regime that new research findings could have been published that nuanced the manifested Potsdam legend, i.e. the interpretation that is based on the sole responsibility of the major powers. These works emphasized the efforts of the Hungarian political parties concerning the deportation of Germans since the spring of 1945. With respect to the circumstances which forced this process partly, i. e. allocation of the Hungarian refugees arriving from the neighbouring countries; the resettlement of Szeklers from Bukovina; internal settlements related to the land reform; Czechoslovak - Hungarian population exchange. ${ }^{18}$

Kaposvár 1985, pp. 559-564; idem, “A hazai németségre vonatkozó rendelkezések végrehajtása Szulokon 1945 és 1949 között”, in: J. Kanyar (ed.), Somogy Megye Múltjából 17, Somogy Megyei Levéltár, Kaposvár 1986, pp. 409-418; idem, "Nemzethüségi vizsgálatok a Somogy megyei németek körében. 1945-1946", in: J. Kanyar (ed.), Somogy Megye Múltjából 19, Somogy Megyei Levéltár, Kaposvár 1988, pp. 309-28; idem, “A német lakosság elleni jogfosztó és korlátozó intézkedések Somogy megyében 1946-1949”, in: J. Kanyar (ed.), Somogy Megye Múltjából 20, Somogy Megyei Levéltár, Kaposvár 1989, pp. 353-362; G. Zielbauer, Adatok és tények a magyarországi németség történetéböl 1945-1949, Akadémiai Kiadó, Budapest 1989; G, Erdmann, Deportálás, kényszermunka. Békési és csanádi németek szovjet munkatáborokban, Békés Megyei Levéltár, Gyula 1990; M. Füzes, Modern rabszolgaság. "Malenkij robot”. Magyar állampolgárok a Szovjetunió munkatáboraiban 1945-1949, Formatív Kft., Budapest 1990; idem, "A rabszolgaszerzés", in: G. Zielbauer (ed.), Magyarországi németek elhurcolása 1944/1945. A kollektív büntetés első állomása. Dokumentumkötet, Magyarországi Németek Szövetsége, Budapest 1990, pp. 85-109; idem, Forgószél. Be- és kitelepitések Délkelet-Dunántúlon 1944- 1948 között. Baranya Megyei Levéltár, Pécs 1990; G. Zielbauer, A magyarországi németség nehéz évtizede 1945-1955, Pannon Mühely Kft., Szombathely-Vép 1990; idem, Die Verschleppung ungarländischer Deutscher 1944/45. Erste Station der kollektiven Bestrafung, Magyarországi Németek Szövetsége, Budapest 1990; T. Bognár, “Adatok a Somogy megyei németlakta települések 1945-1950 közötti helyzetéhez”, in: F. Szili (ed.) Somogy Megye Múltjából 22, Somogy Megyei levéltár, 1991, pp. 221-238.

17 S. Balogh, A népi demokratikus Magyarország külpolitikája 1945-1947, Kossuth Kiadó, Budapest 1988.

18 Á. Tóth, Telepitések Magyarországon 1945-1948 között. A németek kitelepitése, a belső népmozgások és a szlovák-magyar lakosságcsere összefüggései, Bács-Kiskun Megyei Levéltár, Kecskemét 1993, pp. 21-51, R. Marchut, Töréspontok. A Budapest környéki németség második világháborút követö felelösségre vonása és annak elözményei (1920-1948), MTA Társadalomtudományi Kutatóközpont-Magyar Történelmi Társulat-Budaörsi Passió Egyesület. 
In the 1990s, the thematic and methodological horizons of research expanded. In connection with forced migration, the study of the process in a complex way, the joint examination of the great powers, the Hungarian political leadership and the responsibility of society, the establishment of the regional differences resulting from it, the integration of the expellees in Germany and the adversity of the returning people who could not cope with it, also came to the fore. In recent years, luckily, the attention of the newer generation of historians has shifted to the social-historical aspects of the expulsions. ${ }^{19}$ Greater emphasis was placed on exploration of the deportation to the Malenkij robot, during which a significant number of interviews were conducted with survivors. However, in most cases they were prepared without methodological substantiation and were not analysed from the point of view of memory culture. In recent years, several publications have been released as a result of the intensive archival researches that examine the regional differences and the reasons for the deportation of Germans to the Malenkij robot. ${ }^{20}$

The Institut für donauschwäbische Geschichte und Landeskunde (IdGL) and the Institute for Minority Studies of the Hungarian Academy of Sciences (MTA TK KI) in Budapest focused on the decade between 1944 and 1953, which plays a decisive role in the history of both the Hungarian Germans and Hungary. The aim of the project, led by Mathias Beer and Ágnes Tóth, was to make previously unpublished resources available, encourage new research, provide a comparative study of the history of the German minorities in Central and Eastern Europe, and to make it easier for interested members of the public to access these resources. A volume containing about 400 documents presenting the partial results of the research in Hungary, ${ }^{21}$ contrary to previous

Budapest-Budaörs 2014, pp. 185-199; és U. Krisztián, A potsdami határozatok legendái a történetírásban, in: Magyarok 1945-ben. (Szerk. Rainer M. János.), Országos Széchenyi Könyvtár-1956-os Intézet Alapítvány-Gondolat Kiadó, Budapest 2015, pp. 248-302.

19 Á. Tóth, Telepitések Magyarországon 1945-1948 között. A németek kitelepitése, a belsö népmozgások és a szlovák-magyar lakosságcsere összefüggései, Bács-Kiskun Megyei Levéltár, Kecskemét 1993; T. Zinner, A magyarországi németek kitelepitése, Magyar Hivatalos Közlönykiadó, Budapest 2004; Á. Tóth, Hazatértek. A németországi kitelepitésböl visszatért magyarországi németek megpróbáltatásainak emlékezete, Gondolat Kiadó, Budapest 2008; G. Gonda, Kitaszitva. Kényszermigráció, nemzetiségpolitika és földreform németek által lakott Dél-és Nyugat-Dunántúli településeken 1944-1948, Pécsi Egyháztörténeti Intézet, Pécs 2014; R. Marchut, Töréspontok.

20 B. Márkus, “'Malenkij robot' Baranya vármegyében. Döntési folyamatok: hogyan választották ki a civil lakosok közül azokat, akiket a Szovjetunióban végzendő jóvátételi munkára mozgósítottak 1944/1945-ben?”, Múltunk 2014, No. 3, pp. 62-104; Z. Bognar, B Márkus (eds), “'Itt volt a végállomás': Halálos áldozatokkal járó német- és magyarellenes tevékenységek a Kárpát-medencében 1944-1949, Magyarországi Németek Pécs-Baranyai Nemzetiségi Köre, Pécs 2015; B. Márkus, “A magyarországi németek Szovjetunióba deportálása a 'Sváb Törökországból' az egodokumentumok tükrében”, in: P. Miklós (ed.), Mindennapok a Gulágon, Tornyai János Múzeum és Közmüvelődési Központ, Hódmezővásárhely 2017, pp. 49-62, Memorial Books 4, B. Márkus, "Csak egy csepp vér” A német származású civilek Szovjetunióba deportálása Magyarországról 1944-1945, Kronosz, Pécs 2020.

21 Dokumentumok a magyarországi németek történetéhez 1944-1953/ Quellen zur Geschichte der Deutschen in Ungarn 1944-1953. The documents were selected and the introductory study to them was written by: Á. Tóth, Argumentum, Budapest 2018. 
projects on similar topics, such as the collection of resources on Germans living east of the Oder-Neisse line, published at the beginning of the millennium ${ }^{22}$, pays attention both to the processes in Hungary during the period under study and to the history of the Germans in Hungary who left or had to leave their homeland, and who mostly settled in one of the two German states. Thus, in line with the current state of minority research and historical migration research, the document paper seeks a comprehensive approach that examines all three ideal-typical phases of migration processes and thinks in a transnational framework. Thanks to the detailed introductory study in Hungarian and German, the bilingual summaries of the documents, as well as the appendix, the collection of resources can be used well in education, and the Hungarian language sources are included in the regional comparative research.

It should also be noted that from the beginning of the 1990s, the integration of the Germans expelled from Hungary received more emphasis in German historiography. While previously the focus was on the events, the top-down presentation of the integration, and the emphasis on its success, in recent years the presentation of the process from the point of view of the individual communities and individuals has also received attention. ${ }^{23}$ In addition, serious attention was paid to a comparative study of the escape and expulsion of the German population in Central and Eastern Europe at the end of the Second World War. ${ }^{24}$

Although several volumes of documents and analyses deal with the theoretical statements of the political power regarding nationalities in the period of socialism, insignificant attention has been paid to the study of the history of Germans in Hungary

22 W. Borodziej, H. Lemberg (eds), “Unsere Heimat ist uns ein fremdes Land geworden ... ”. Die Deutschen östlich von Oder und Neiße 1945-1950. Dokumente aus polnischen Archiven, 4 Vol., Verlag Herder-Institut, Marburg 2000-2004.

23 M. Füzes, Valami Magyarországon maradt, Baranya Megyei Levéltár, Pécs 1999; J. Mayer, „Most menekültnek hívnak...”, Pécs 2001, PhD Dissertation; A. Kossert, Kalte Heimat. Die Geschichte der Deutschen Vertriebenen nach 1945, Siedler, München 2008; J. Mayer, “"Ennek az idegen földnek kell hazánknak lennie...' Az elüzött észak-bácskai németek beilleszkedési problémái Nyugat-Németországban”, Forrás, July 2015, pp. 18-43; M. Prosser-Schell, “Az elüzött magyarországi németek megérkezésének és integrációjának néhány aspektusa Észak-Badenben és Délnyugat-Németországban 1945-1946 után”, Pro Minoritate, Summer 2016, pp. 5-18; C. Schell: „...aber wenn man sich Deutsch bekennt darf man nicht mehr nachhause wenn es einmal soweit kommt/ ...de ha az ember németnek vallja magát, akkor nem mehet majd haza, ha arra kerül sor". Adatok egy Württembergbe kiüzött budaörsi család integrációjához magánleveleik tükrében", Pro Minoritate, Summer 2016, pp. 19-46.

24 See inter alia W. Benz (ed.), Die Vertreibung der Deutschen aus dem Osten. Ursachen, Ereignisse, Folgen, Fischer Verlag, Frankfurt am Main, first publisched Fischer Verlag, 1985, 2. edition: Fischer Taschenbuch Verlag, 1995; R.G. Paschka et al. (ed.), Nationale Frage und Vertreibung in der Tschechoslowakei und Ungarn 1938-1945, Verlag der Österreichischen Akademie der Wissenschaften, Wien 1997; M. Beer, ,Zwangsmigrationen in Südosteuropa während des Zweiten Weltkriegs und danach (1939-1950)", Geschichte und Unterricht 2011, No. 3-4, pp. 144-158; D. Brandes, H. Sunhdhausen, S. Troebst, Lexikon der Vertreibungen. Deportation, Zwangsausiedlung und ethnische Säuberung im Europa des 20. Jahrhundert, Böhlau Verlag, Wien-Köln-Weimar 2010; M. Beer, Flucht und Vertreibung der Deutschen. Voraussetzungen, Verlauf, Folgen, C.H. Beck, München 2011. 
between 1950 and 1990 so far. In connection with the decades after 1950, in respect to three areas - national politics, the economic and social situation of minorities, mother tongue education - the interested person can rely on the considerable previous research results. Several volumes of documents and analyses deal with the principled resolutions of the political authorities related to nationalities, the general political and civic situation of the minorities in Hungary, including the Germans. ${ }^{25}$ Some of the works in the period published on national politics and the use of concepts have a direct ideological definition, but they cannot be bypassed in terms of the changing position of the authorities in relation to minorities. ${ }^{26}$ The first summary work was also published by István Fehér for this period. ${ }^{27}$ The author's title selection - Last minute. Nationalities of Hungary 1945-1990 - indicates that he considered that as a result of the socialist nationality policy the minorities had reached the threshold of mergence and assimilation. Relying on a significant source base, the volume has a Marxist approach, primarily event-centric, with measures of political authorities as its guideline, and is explicitly descriptive. It does not examine the motivations and impact mechanisms of decisions, nor does it pay attention to the internal structure of communities. The range of discovered documents - first of all the documents of the various bodies of the MDP (Hungarian Working People's Party) and the MSZMP (Hungarian Socialist Workers' Party) - would have allowed a more structured discussion by applying more consistent sources of criticism. Nevertheless, in examining the minorities in the socialist period, the volume is indispensable only because of its factual material.

Research on the economic and social situation of minorities considers the changes in localities. This perspective is justified in several respects. On the one hand, obviously not independent of the political aspiration to see and display the society as homogeneous unit, only very fragmentary statistical data are available for the analysis of the fault lines of society from the national-ethnic point of view - education, occupational structure. On the other hand, the top-down perspective is not suitable for showing the personal and community aspects of political and economic structural change. ${ }^{28}$

25 G. Seewann, “A magyar nemzetiségi politika mérlege az '50-es évektől napjainkig”, in: idem, Ungarndeutsche und Ethnopolitik, Osiris-MTA Kisebbségkutató Mühely - Magyarországi Németek Országos Önkormányzata, Budapest 2000, pp. 69-74; G. Föglein, Nemzetiség vagy kisebbség?, Ister Kiadó, Budapest 2000; S. Balogh, L. Sipos (eds), A magyar állam és a nemzetiségek. A magyarországi nemzetiségi kérdés történetének jogforrásai 1848-1993, Napvilág Kiadó, Budapest 2002; Pártállam és nemzetiségek 1950-1973, It was compiled, annotated, and the introductory study to it was written by: Ágnes Tóth.), Bács-Kiskun Megyei Önkormányzat Levéltára, Kecskemét 2003; Á. Szesztay, Nemzetiségi kérdés a Kárpát-medencében 1956-1962. Az ötvenhatos forradalom hatása a kelet-közép-európai kisebbségpolitikára, MTA Kisebbségkutató Intézet-Gondolat Kiadói Kör, Budapest 2003; B. Dobos, "Nyitás vagy visszarendeződés? Az 1968as párthatározat és következménye”, Kisebbségkutatás 2008. No. 3, pp. 385-405.

26 D. Csatári (ed.), Nemzetiségi kérdés - nemzetiségi politika, Kossuth Kiadó, Budapest 1968.

27 I. Fehér, Az utolsó percben. Magyarország nemzetiségei 1945-1990, Kossuth Kiadó, Budapest 1993, p. 157. I have already mentioned Loránt Tilkovszky's works dealing with the characteristics of Hungarian nationality policy in the $20^{\text {th }}$ century.

28 W. Aschauer, Zur Produktion und Reproduktion einer Nationalität. Die Ungarndeutschen, Franz Steiner Verlag, Stuttgart 1992. 
In connection with the ethnic mother tongue education, we may rely mainly on the works of Gizella Föglein, who mainly dealt with its legal regulation. ${ }^{29}$

\section{Abstract \\ Research Questions and Methodological Approaches in the Literature on the History of the German Minority in Hungary between 1945 and 1955}

In my study, I summarise the content issues, methodological approaches and the most important results from historical literature dealing with the history of the German minority in Hungary during the decade after World War II. It can be said that the historical research on the expulsion of Germans from Hungary up to 1990 was characterised by a positivist, descriptive and event-centric approach. The research questions were organised and based on the terms of the Potsdam Agreement in relation to Hungary. In connection with both the content and methodological issues, I touch upon missing aspects and more complex possible research approaches.

Keywords: Hungary, German minority, expulsion, education, historiography.

Translation from Hungarian by István Honti

29 G. Föglein, Nemzetiség vagy kisebbség?, Ister Kiadó, Budapest 2000; eadem, Etnikum és educatio. A magyarországi nemzetiségek és alsó fokú oktatásuk állami szabályozása 1945-1985, Napvilág Kiadó, Budapest 2006. 